\title{
A Morphological and Molecular Analysis of a Bloom of the Filamentous Green Alga Pithophora
}

\author{
Blia Lor ${ }^{1,2}\left(\mathbb{D}\right.$, Merry Zohn ${ }^{1,3}$, Marcus J. Meade ${ }^{4}$, A. Bruce Cahoon ${ }^{4}$ and Kalina M. Manoylov ${ }^{1, *(D)}$ \\ 1 Department of Biological and Environmental Sciences, Georgia College and State University, \\ Milledgeville, GA 31061, USA; blia.lor@bobcats.gcsu.edu (B.L.); merry.zohn@bobcats.gcsu.edu (M.Z.) \\ 2 US AmeriCorps, Conservation Minnesota and Iowa, 60 Plato Blvd, Saint Paul, MN 55107, USA \\ 3 Oak Ridge Institute for Science and Education, Agricultural Research Services, U.S. Department of \\ Agriculture, 600 E. Greenfield Ave., Milwaukee, WI 53204, USA \\ 4 Department of Natural Sciences, The University of Virginia's College at Wise, 1 College Ave., \\ Wise, VA 24293, USA; mjm6mv@uvawise.edu (M.J.M.); abc6c@uvawise.edu (A.B.C.) \\ * Correspondence: kalina.manoylov@gcsu.edu; Tel.: +1-478-445-2439
}

Citation: Lor, B.; Zohn, M.; Meade, M.J.; Cahoon, A.B.; Manoylov, K.M. A Morphological and Molecular Analysis of a Bloom of the Filamentous Green Alga Pithophora. Water 2021, 13, 760. https:// doi.org/10.3390/w13060760

Academic Editor: John R. Beaver

Received: 25 January 2021

Accepted: 6 March 2021

Published: 11 March 2021

Publisher's Note: MDPI stays neutral with regard to jurisdictional claims in published maps and institutional affiliations.

Copyright: (c) 2021 by the authors. Licensee MDPI, Basel, Switzerland. This article is an open access article distributed under the terms and conditions of the Creative Commons Attribution (CC BY) license (https:// creativecommons.org/licenses/by/ $4.0 /)$.

\begin{abstract}
Filamentous representatives of Cladophorales (Chlorophyta) are major contributors to algal biomass of littoral communities. In the present study, community analysis of a reported bloom in the Ogeechee River in Georgia provided an opportunity to combine morphological and genetic analyses with ecological information related to an understudied nuisance alga. A polyphasic approach of incorporating genotypic and phenotypic methods led to the identification of the algal community as Pithophora roettleri (Roth) Wittrock. Morphological analysis showed a monospecific community based on the average length and diameter of the heterosporous intercalary and terminal akinetes, along with the diameter of the principal filaments. Single-gene and concatenated-gene phylogenetic analyses of the LSU (28S rRNA) and SSU (18S rRNA) markers further confirmed this species identification. In this study, we conducted a morphological treatment of $P$. roettleri, produced 17 novel gene sequences, and produced a new, schematic diagram illustrating the four steps of the asexual reproduction of an intercalary akinete. Morphological characteristics, like the position and shape of akinetes documented here, and the availability of genetic sequences can improve identification and further ecological understanding of filamentous green algae. Flowing mats of $P$. roettleri, like those observed in this study, can lower light availability for other biota and structurally alter the habitat.
\end{abstract}

Keywords: Pithophora taxonomy; biology; life cycle; morphological and molecular identification

\section{Introduction}

In aquatic ecosystems, algal communities are composed of diverse and coexisting species. Increase in nutrient loading due to run-off or high evaporation rates can lead to a decline in algal diversity and the development of a monospecific community, such as representatives of green filamentous algae from the order Cladophorales [1,2]. Within the order Cladophorales, Pithophora and Cladophora are macroscopic green, thread-like branching filaments that are often misidentified as one another [3], especially as young filaments. Pithophora, described as "horsehair," grows as coarser, less flexible, narrower filaments compared to the "cotton mat" filament texture of Cladophora [4,5]. Facultative formation of akinetes can be a distinguishing characteristic for Pithophora identification, but those are formed only during reproduction and akinete number, structure, and arrangement need more research. The abundance and wide geographic distribution of these two genera make them ecologically important to oxygen production, habitat heterogeneity, and nutrient cycling [6,7].

Considered ecosystem engineers, Pithophora and Cladophora provide ideal habitats for epiphytes and invertebrates due to their thick cellulose cell wall and lack of external 
mucilaginous layer [8,9]. Up to $85 \%$ of Pithophora species may be supportive of epiphytic assemblages [10]. Despite their ecological value, the persistence of Pithophora and Cladophora floating mats, under favorable conditions, can make them nuisance algae. Their thick growth shades the water column and senescing cells provide nutrients that maintain high bacteria densities. As a result, their growth can alter the structure of the ecosystem and its biodiversity. The environmental conditions that support these massive "surface water" growths can further be triggered by anthropogenic activities (e.g., agriculture, fertilizer run-off, and wastewater treatments) [11,12]. Blooms of these genera can also result in multiple negative economic effects by reducing the quality of drinking water, producing unpleasant odors and appearances, clogging of water pipes, and limiting recreational activities $[11,13]$.

More than 40 species of Pithophora (Index Nominum Algarum, http:/ / ucjeps.berkeley. edu/INA.html, accessed 8 March 2021) have been described since its original description, but the overlap of phenotypic plasticity in morphological characters between species complicates taxonomic and phylogenetic studies [14]. Species identification based solely on filament diameter along with another diagnostic character can easily lead to the misidentification of this genus and the species within it [15]. Previous research based only on morphological characteristics lead to the designation of two taxa, Pithophora roettleri (Roth) Wittrock and Pithophora oedogonia (Mont.) Wittrock $[16,17]$. Generally, diagnostic characters used in taxonomic identification depended upon the shape, size, and arrangement of akinetes and vegetative cells [14]. However, the shape of intercalary akinetes within the length of a filament was the only distinguishable morphological character that separated Pithophora species [16].

Besides vegetative fragmentation, Pithophora reproduces asexually by the formation of akinetes as its only other known mode of reproduction [14,18-21]. Cellular structure, composition, and morphology differentiate akinetes from growing vegetative cells [22]. Akinetes are non-motile, reproductive, and perennating spore-like structures with thicker cell walls, varying in shape and size from cylindrical to cask-shaped. Newly formed akinetes are distinguished by their green pigmentation that results from the increased accumulation of chlorophyll in their chloroplasts $[21,23,24]$. As metabolic and photosynthetic activities decrease after maturation, this green pigmentation later transitions into a blackish color as seen in older akinetes.

Although the shape of the intercalary akinetes is an essential morphological character in Pithophora identification, the distinction between isosporous and heterosporous akinetes remains unclear in published taxonomic literature. Akinetes' shape and size are suggested to depend upon their stages of growth $[14,16]$, but these have not been shown. As described by $\mathrm{O}^{\prime} \mathrm{Neal}$ and Lembi [23], akinete germination is attributed to four phases of physiological changes: (1) size of akinete (germination tube) increasing as respiratory rates increases; (2) protrusion developing from the germination tube; (3) germination tube elongating as photosynthetic activity, chlorophyll synthesis, and water content increase; and (4) germination tube transitioning into a vegetative cell as respiratory rates decrease.

Currently, molecular analyses can complement morphological research. The large, multinucleate cells of Pithophora contribute to its complexity and large sized nuclear genome which is estimated to be $882 \mathrm{Mb}$ [25]. In contrast to other algal groups, the majority of the highly variable chloroplast genes of Cladophorales (e.g., rbcL, tufA, $p s a \mathrm{~A}, p s a \mathrm{~B}$ ) have proven difficult to PCR amplify except for the $r b c \mathrm{~L}$ gene of Chaetomorpha valida (J.D. Hooker \& Harvey) Kützing $[19,26]$. This difficulty is most likely a result of the unusual plastome structure and divergent sequences found in Cladophorales species. They do not have the single circular chromosome structure typical of most chloroplast genomes. Instead, they appear to have a highly reduced set of linear fragments ranging from 1.5 to $3.0 \mathrm{~kb}$, each carrying one or two genes [26].

The objectives of this study were to: (1) assess the morphological characteristics of a Pithophora species to refine the differences between it and other closely related taxa, (2) produce DNA sequences from a Pithophora species that could be used in molecular 
phylogenetic techniques, and (3) compare the results of the morphological and molecular phylogenetic analyses.

\section{Materials and Methods}

As part of an environmental monitoring program for Georgia College and State University algae collection (2007 to current), the Ogeechee River was reported as an impacted site due to its low water depth and nuisance algal growth. Consequently, an algal community was sampled from the shoreline of the Ogeechee River in Jewell, Georgia $\left(33^{\circ} 17^{\prime} 40.812^{\prime \prime} \mathrm{N}, 82^{\circ} 45^{\prime} 45^{\prime \prime} \mathrm{W}\right.$, located at the crossing of the river at Macon Highway) in October 2016. The preliminary identification and evaluation by microscopic analysis revealed a monospecific, filamentous alga. This algal community was cultured in an artificial environment with Bold's medium (Sigma-Aldrich, B5282). The culture was maintained at conditions of $20^{\circ} \mathrm{C}$ with a light-dark photoperiod of $12: 12 \mathrm{~h}$ for a month in preparation for morphological analysis and DNA extraction for phylogenetic analyses.

Morphological characters of the monospecific, filamentous community were observed under a Leica DM2500 microscope with a Leica DFC295 Camera at Georgia College and State University (Leica Microsystems, Wetzlar, Germany). Most observations were at 100× and 400× magnification. Qualitative characters of the thallus examined: organization and formation of branches, shapes and sizes of vegetative and reproductive cells, and characteristics of chloroplasts. From 12 algal specimens and 108 cells analyzed, the length and diameter of the principal filaments, intercalary akinetes, and terminal akinetes were observed and quantified. Preserved dried algal materials were deposited at the Georgia College and State Natural History University Museum Algae Collection (Accession number for dried algal material GCAC5001).

Total genomic DNA was extracted from the cultured alga using the DNeasy PowerBiofilm Kit (Qiagen, Santa Clarita, CA, USA), according to the manufacturer's protocol. DNA concentrations and A260/A280 ratios were determined with a Nanodrop 2000 UVVIS spectrophotometer (ThermoFisher Scientific, Waltham, MA, USA). DNA samples were stored at $-20^{\circ} \mathrm{C}$, then shipped to the commercial sequencing facility, GeneWiz (Plainfield, NJ, USA), who prepared a library and deep sequenced total DNA using Illumina's MiSeq technology. The raw sequence data have been archived in NCBI's Sequence Read Archive (PRJNA591002) and used in another study [27]. Sequence reads were trimmed, paired, and de novo assembled using the bioinformatics platform, Geneious Prime v. 2019.0.3 (Biomatters Ltd., Auckland, New Zealand, v. 8.1.9).

For phylogenetic confirmation of the species identification, the LSU and SSU markers were concatenated and used to reconstruct molecular phylogenetic trees to infer the speciesidentification of the monospecific, filamentous community. The sequences used in the alignments (accession numbers in Table 1) were modified from the dataset of [17], with the addition of Pithophora sp. 'Kamigori' in the SSU dataset analyses (Table 2). Similar LSU and SSU homologs were identified using the Basic Local Alignment Search Tool (https: / / blast.ncbi.nlm.nih.gov / Blast.cgi, accessed 15 January 2020 [28]) and other homologs included from Boedeker et al. [17], with Trentepohlia sp. and Ulva fasciata Delile as two outgroup taxa.

The concatenated LSU and SSU sequences were preliminarily aligned using MUSCLE (multiple sequence comparison by log-expectation) $[29,30]$ with default parameters in MEGA v7.0 (https:/ / www.megasoftware.net/ accessed on 16 January 2021) Molecular Evolutionary Genetics Analysis across computing platforms [29]. The final matrix was comprised of 24 taxa (the novel sequence, 21 homologous taxa, and two outgroup taxa) sequences. The final alignment of the sequences was trimmed to 2325 positions. 
Table 1. GenBank accession numbers of sequences used from previously published taxa under the appropriate tree clades (modified from [17]) / = no information.

\begin{tabular}{|c|c|c|}
\hline Taxon & LSU & SSU \\
\hline $\begin{array}{c}\text { Aegagropila } \\
\text { Aegagropila linnaei Kützing }\end{array}$ & $\begin{array}{l}\text { EU655697.1 } \\
\text { EU655701.1 }\end{array}$ & $\begin{array}{l}\text { FR719925.1 } \\
\text { FR873098.1 }\end{array}$ \\
\hline $\begin{array}{c}\text { Aegagropilopsis } \\
\text { Cladophora clavuligera Grunow } \\
\text { Cladophora sterrocladia Skuja } \\
\text { Cladophora sp. 'Tateyama' }\end{array}$ & $\begin{array}{l}\text { FR719939.1 } \\
\text { FR719940.1 } \\
\text { / }\end{array}$ & $\begin{array}{l}\text { FR719927.1 } \\
\text { FR873099.1 } \\
\text { AB062711.1 }\end{array}$ \\
\hline $\begin{array}{c}\text { Basicladia (=Arnoldiella) } \\
\text { Arnoldiella conchophila V.V. Mill. } \\
\text { Basicladia cf. chelonum (Collins) } \\
\text { W.E. Hoffm. et. Tilden } \\
\text { Basicladia kosterae (C. Hoek) Garbary }\end{array}$ & $\begin{array}{c}/ \\
\text { FR719947.1 } \\
\text { FR719946.1 }\end{array}$ & $\begin{array}{l}\text { AB062712.1 } \\
\text { FR719934.1 } \\
\text { AB078730.1 }\end{array}$ \\
\hline $\begin{array}{c}\text { Cladophora } \\
\text { Cladophora albida (Nees) Kützing } \\
\text { Cladophora rupestris (Linnaeus) Kützing } \\
\text { Cladophora vagabunda (Linnaeus) } \\
\text { van den Hoek }\end{array}$ & $\begin{array}{l}\text { AM503433.1 } \\
\text { AJ544764.1 } \\
\text { AJ544760.1 }\end{array}$ & $\begin{array}{c}\text { Z35317.1 } \\
\text { Z35319.1 } \\
\text { AB062710.1 }\end{array}$ \\
\hline $\begin{array}{c}\text { incertae sedis } \\
\text { Basicladia okamurae (Ueda) Garbary } \\
\text { Basicladia ramulosa Ducker }\end{array}$ & $\begin{array}{l}\text { FR719949.1 } \\
\text { FR719948.1 }\end{array}$ & $\begin{array}{l}\text { FR719936.1 } \\
\text { FR719935.1 }\end{array}$ \\
\hline $\begin{array}{c}\text { Pithophora } \\
\text { Pithophora sp. 'Kamigori' } \\
\text { Pithophora cf. polymorpha Wittrock } \\
\text { Pithophora roettleri (Roth) Wittrock }\end{array}$ & $\begin{array}{c}/ \\
\text { FR873096.1 } \\
\text { FR719942.1 }\end{array}$ & $\begin{array}{l}\text { AB062713.1 } \\
\text { FR873097.1 } \\
\text { FR719930.1 }\end{array}$ \\
\hline $\begin{array}{c}\text { Pseudocladophora } \\
\text { Cladophora conchopheria Sakai } \\
\text { Cladophora horii C. Hoek et. Chihara }\end{array}$ & $\begin{array}{l}\text { FR719951.1 } \\
\text { AJ544728.1 }\end{array}$ & $\begin{array}{l}\text { AB062705.1 } \\
\text { AB078731.1 }\end{array}$ \\
\hline $\begin{array}{c}\text { Wittrockiella } \\
\text { Wittrockiella amphibia (Collins) } \\
\text { Boedeker et. G.I. Hansen } \\
\text { Cladophorella calcicola F.E. Fritsch } \\
\text { Wittrockiella layallii (Harvey) } \\
\text { C. Hoek, Ducker et. Womersley } \\
\text { Wittrockiella sp. }\end{array}$ & $\begin{array}{l}\text { GU384873.1 } \\
\text { FR719944.1 } \\
\text { GU198503.1 } \\
\text { FR719943.1 }\end{array}$ & $\begin{array}{l}\text { FR719932.1 } \\
\text { GU198502.1 } \\
\text { FR719931.1 }\end{array}$ \\
\hline $\begin{array}{l}\text { Outgroup taxa } \\
\text { Trentepohlia sp. } \\
\text { Ulva fasciata Delile }\end{array}$ & $\begin{array}{c}\text { FR719952.1 } \\
\text { AJ544726.1 }\end{array}$ & $\begin{array}{l}\text { FR719938.1 } \\
\text { AB425964.1 }\end{array}$ \\
\hline
\end{tabular}

Phylogenetic analyses were performed with the following character-based methods, maximum parsimony (MP), maximum likelihood (ML), and Bayesian inference (BI). The criterion for the best tree score for MP, ML, and $\mathrm{BI}$ are as follows: the minimum number of changes, the log-likelihood, and the posterior probability generated from log-likelihood. ML and MP analyses were implemented using MEGA v7.0, whereas the BI analyses were performed using the MrBayes v3.2.6 plug-in in the Geneious (Biomatters LLC, Auckland, NZ) platform [31]. The best nucleotide substitution model for each dataset and methodology was determined by MEGA v7.0. The ML and MP analyses were performed using the Kimura 2-parameter model with invariant sites and gamma distribution, which is equivalent to the Hasegawa-Kishino-Yano, 85 model with inverse gamma distribution for the BI analyses. The bootstrap probabilities were calculated with 1000 bootstrap [32-34] replicates for all ML analyses. The BI analyses consisted of 1,000,000 generations, sampled every 100 generations. A burn-in sample of $25 \%$ of the retained BI trees were removed before calculating the majority rule consensus tree. The posterior probabilities of the BI 
trees were calculated using a Metropolis-coupled Markov chain, Monte Carlo approach. In all trees, gaps were treated as missing data and all sites were weighted equally. All resulting trees were visualized and annotated in TreeGraph v2.14.0-771 beta (BMC Bioinformatics, London, UK) [35].

Table 2. Plastid and mitochondrial gene markers sequenced for the present study.

\begin{tabular}{|c|c|c|c|c|}
\hline Function & Gene & Organelle & $\begin{array}{c}\text { GenBank Accession } \\
\text { Number }\end{array}$ & $\begin{array}{c}\text { Percent Identity to } \\
\text { Pithophora sp. (UTEX 787) }\end{array}$ \\
\hline \multirow{3}{*}{ ATP synthase } & $\operatorname{atp} \mathrm{A}$ & Plastid & not archived & nd \\
\hline & $\operatorname{atpB}$ & Plastid & MN049190 & $94.3 \%$ \\
\hline & $\operatorname{atp} \mathrm{H}$ & Plastid & MN049185 & $97.2 \%$ \\
\hline \multicolumn{5}{|c|}{ Cytochrome $b_{6} f$ complex } \\
\hline & petA & Plastid & MN049188 & $85.9 \%$ \\
\hline & petB & Plastid & MN049187 & $93.7 \%$ \\
\hline \multicolumn{5}{|l|}{ Photosystem I } \\
\hline & psaA & Plastid & not archived & nd \\
\hline & $p s a \mathrm{~B}$ & Plastid & MN049189 & $76.2 \%$ \\
\hline \multicolumn{5}{|l|}{ Photosystem II } \\
\hline & $p s b \mathrm{~A}$ & Plastid & not archived & nd \\
\hline & $p s b \mathrm{~B}$ & Plastid & not archived & nd \\
\hline & $p s b C$ & Plastid & MN049186 & $90.3 \%$ \\
\hline \multicolumn{5}{|l|}{ Rubisco } \\
\hline & $r b c L$ & Plastid & MN049191 & $88.3 \%$ \\
\hline \multicolumn{5}{|c|}{$\begin{array}{c}\text { Cytochrome c oxidase } \\
\text { subunit }\end{array}$} \\
\hline & $\operatorname{cox} 1$ & Mitochondria & MN049192 & nd \\
\hline \multicolumn{5}{|l|}{ Ribosome } \\
\hline & $\begin{array}{l}\text { SSU, ITS1, 5.8S, } \\
\text { ITS2, LSU }\end{array}$ & Nucleus & MN017042 & $100 \%$ * \\
\hline
\end{tabular}

* The SSU (18S) portion matched Pithophora roettleri (GenBank FR719330) with 100\% identity, nd- not detected.

\section{Results}

\subsection{Morphological Analyses}

Macroscopically, branching green filament developed with the dark colored cells, along the principal filaments of older filaments, indicated akinetes (Figure 1). Older filaments with akinetes had a coarser texture compared to younger filaments with no akinetes. All specimens were observed to be rich in nuclei and chloroplasts containing pyrenoids in the vegetative and reproductive cells. The diameter of the principal filaments collected from the field averaged $146 \pm 5.92 \mu \mathrm{m}$ and ranged from 120 to $182 \mu \mathrm{m}$; significant filament thinning was observed in cultures (Figures 2-4). The principal filaments were composed of a series of long cylindrical cells that varied in length (Figures 2-5). Furthermore, the apical vegetative cells of the principal filaments and branches were significantly longer than the enclosed vegetative cells. Vegetative cells of colorless and chlorophyll-colored protoplasm were observed throughout the fertile specimens. The subapical cells of the principal filaments consisted of a single parietal layer of chloroplasts (e.g., Figure 2A). Occasionally, the chloroplast layer was distorted and assumed a wide, net-like arrangement (Figures 2B and 3A). 


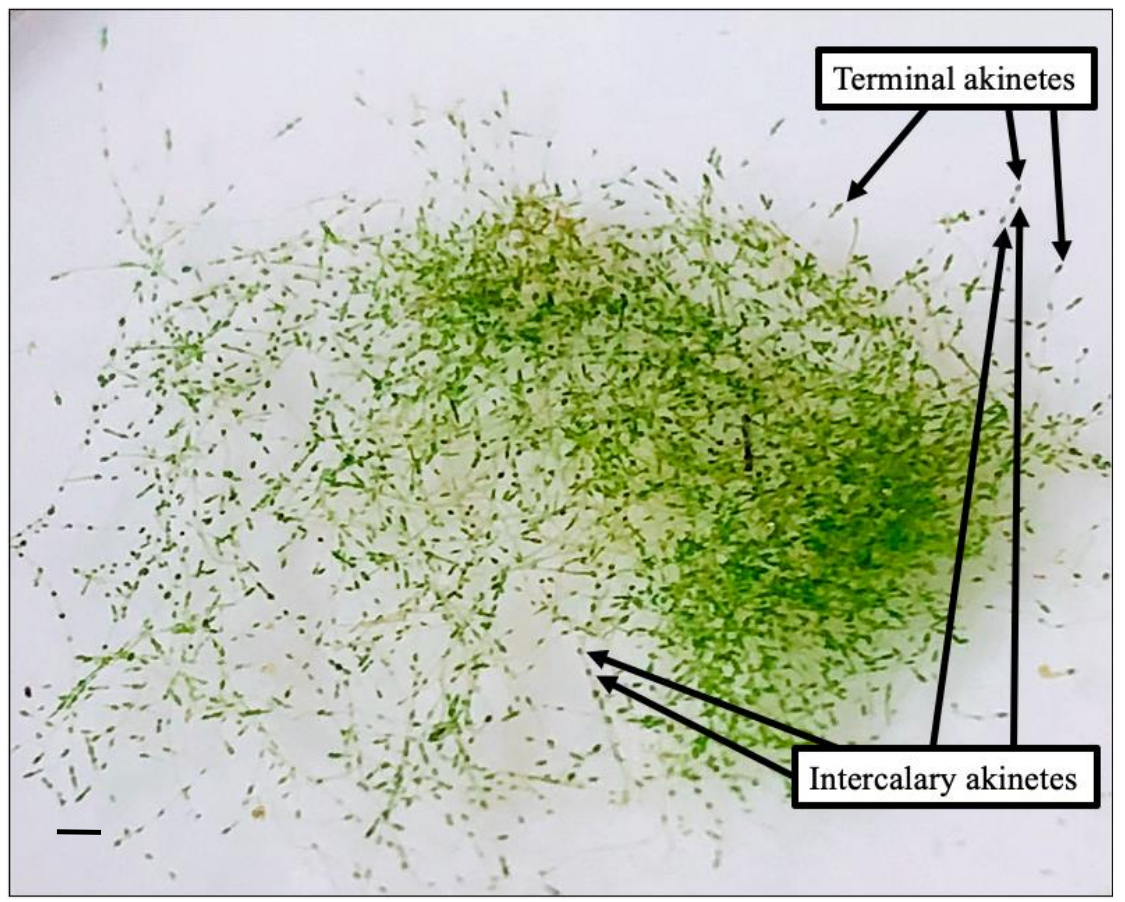

Figure 1. Macroscopic view of Pithophora roettleri with darkening cells along the filaments being characterized as akinetes. Image 12 November 2016, scale bar $1 \mathrm{~cm}$.

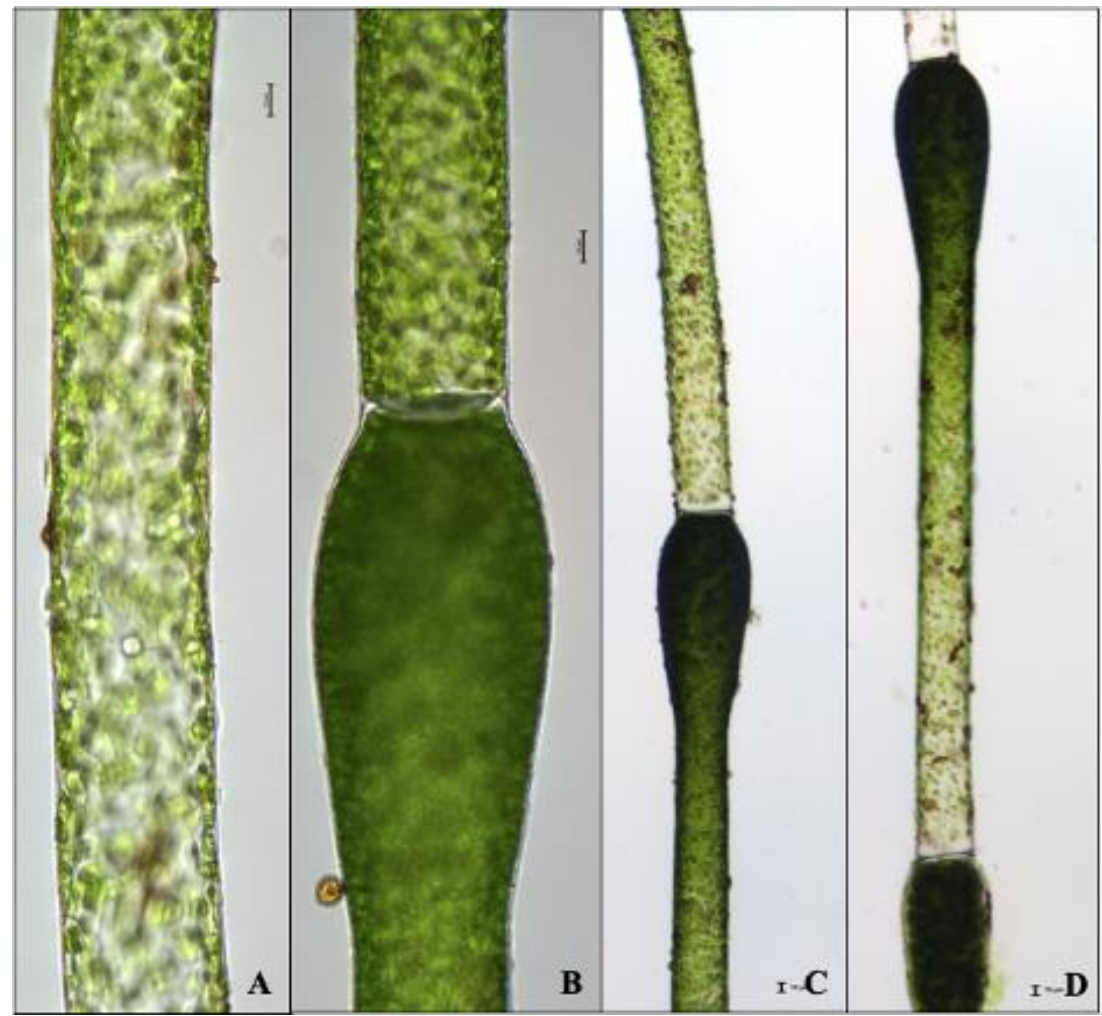

Figure 2. Characters of the principal filaments of Pithophora roettleri. (A,B) $400 \times$ magnification. (C,D) $100 \times$ magnification. (A) Single, parietal layer of chlorophyll granules. (B-D) Formation of intercalary akinetes on the upper end of vegetative cells. (D) Interspersed akinetes. Scale bar $=10 \mu \mathrm{m}$. 


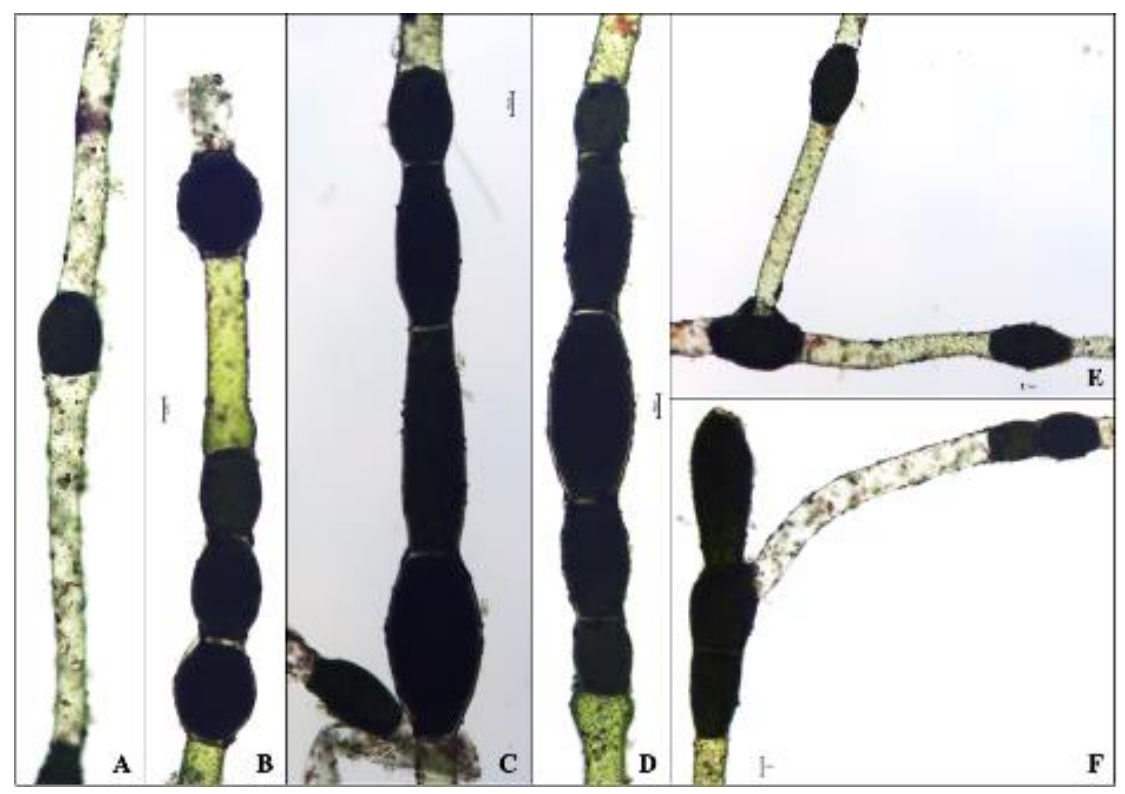

Figure 3. Mature, heterosporous akinetes of the principal filament or of germinated branches of Pithophora roettleri at $100 \times$ magnification. $(\mathbf{A}, \mathbf{B}, \mathbf{E}, \mathbf{F})$ Interspersed akinetes. $(\mathbf{B}-\mathbf{D}, \mathbf{F})$ Rows of akinetes. (F) Terminal cells bearing triple akinetes. $(\mathbf{E}, \mathbf{F})$ Akinetes with germinating branches bearing akinetes. Scale bar $=10 \mu \mathrm{m}$.

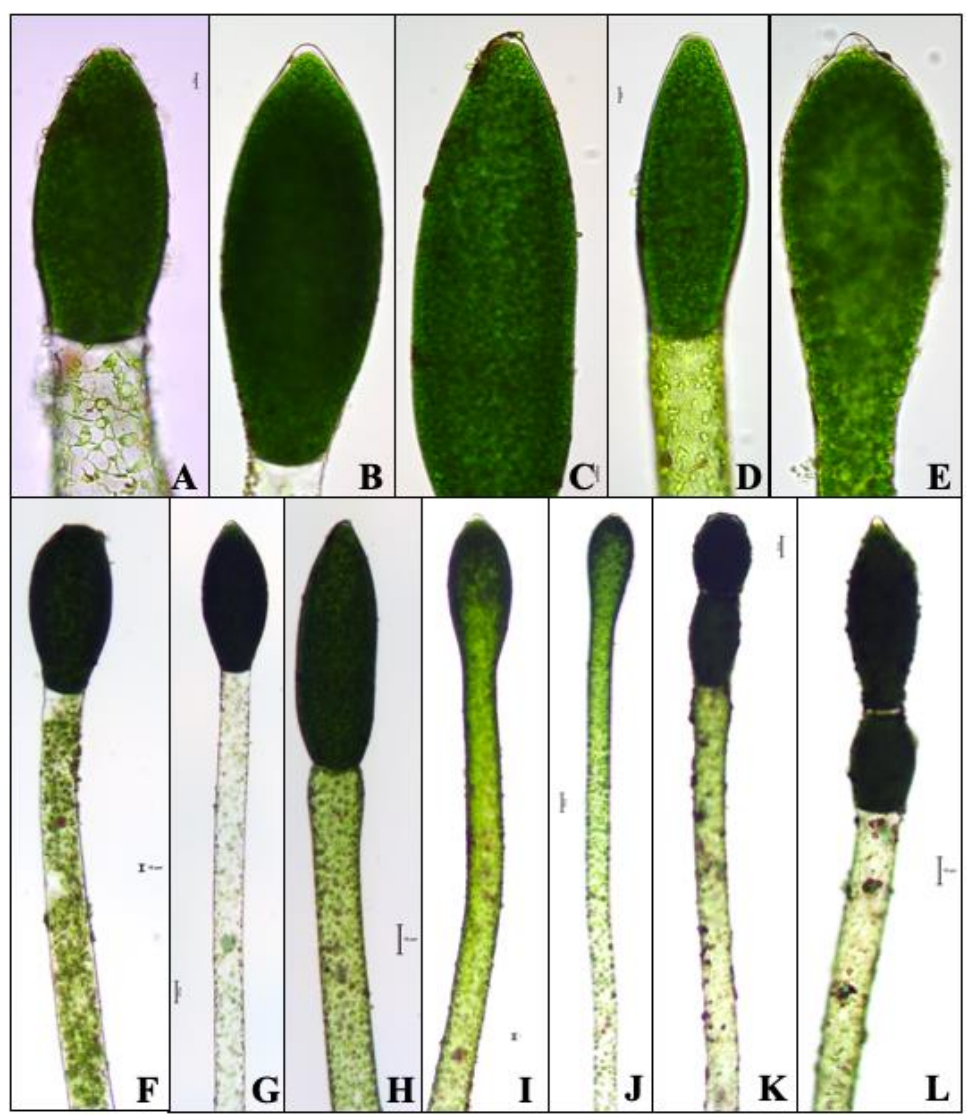

Figure 4. Terminal akinetes of Pithophora roettleri with variable shapes and sizes divided with or without a transversal, parting cell wall. (A-E) 400× magnification. (F-L) $100 \times$ magnification. (A) Netlike chloroplast, $(\mathbf{F})$ present cell wall, $(\mathbf{J})$ absent cell wall, $(\mathbf{K}, \mathbf{L})$ twin akinetes of the terminal cell. Scale bar $=10 \mu \mathrm{m}$. 


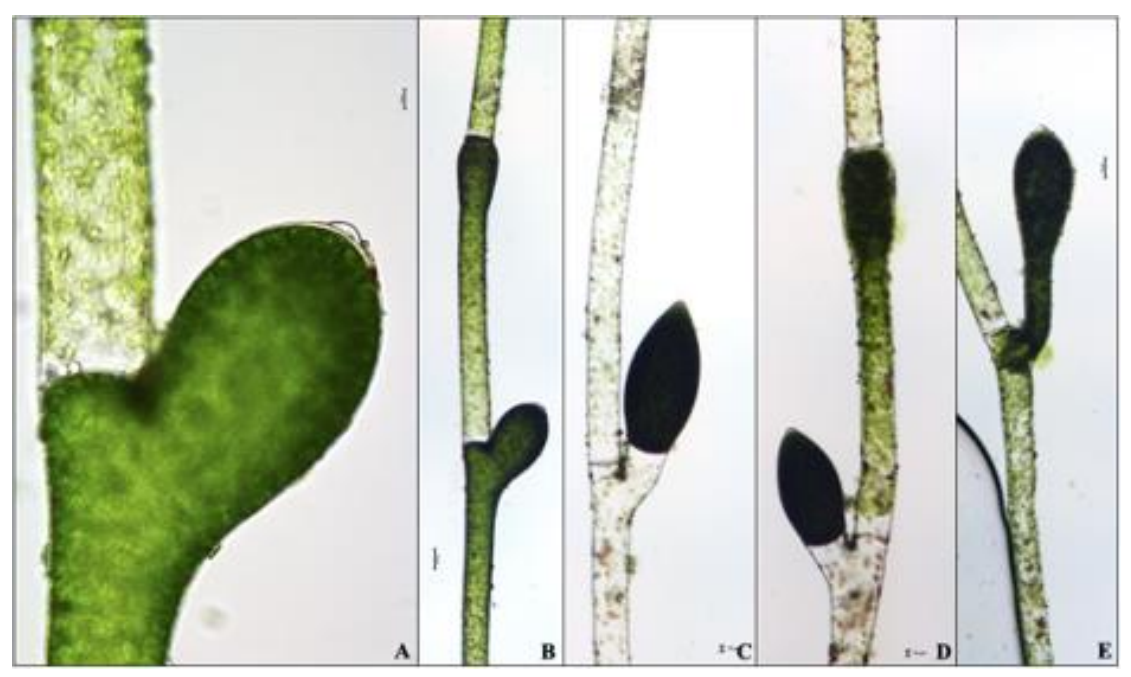

Figure 5. Germination of an intercalary akinete of Pithophora roettleri divided with or without a transversal, parting cell wall. (A) $400 \times$ magnification. (B-E) $100 \times$ magnification. (A-D) Interrupted germination of a branch process with an akinete forming (A) within the same cell with some of the upper end of the akinetes assuming a beak-like process. (E) Germinated branch at a $45^{\circ}$ angle with the upper end of the branch process transformed into an akinete. Scale bar $=10 \mu \mathrm{m}$.

Newly formed and matured akinetes were observed throughout the principal filaments. The average length of the intercalary and terminal akinetes were $226 \pm 3.50 \mu \mathrm{m}$ (range 188-250 $\mu \mathrm{m}$ ) and $233 \pm 1.03 \mu \mathrm{m}$ (range 198-258 $\mu \mathrm{m}$ ), respectively. Branches bearing akinetes had an average length of $125 \pm 3.07 \mu \mathrm{m}$ (range 100-150 $\mu \mathrm{m}$ ). Numerous heterosporous, intercalary akinetes of the principal filaments were newly formed akinetes based on their green pigmentation (Figure 2B-D). The intercalary akinetes of the principal filament with no transversal parting cell wall (Figure 2) assumed more of an invariable caskshaped form in comparison to the variable shapes and sizes of the developed heterosporous intercalary akinetes (Figure 3) and terminal (Figure 4) akinetes. All of the terminal cells attained a cone-like tip, whereas the form of the akinetes ranged from cask-shaped (e.g., Figure $4 \mathrm{~A}$ ) to cylindrical (e.g., Figure $4 \mathrm{H}$ ). Matured, blackish intercalary akinetes of the principal filament were either interspersed or arranged in series of three (Figure 3C) and five (Figure 3D). Terminal twin and triple akinetes were also observed on the principal filaments (Figures $3 \mathrm{~F}$ and $4 \mathrm{~K}-\mathrm{L}$ ). These arrangements of akinetes were more common within the principal filaments than in the branches. The vegetative and reproductive cells were rich in multi-nucleate protoplasm and chloroplasts, which are irregularly arranged to form a parietal, net-like structure or reticulum (Figures 2 and 4). Intercalary akinetes formed in multiple rows (e.g., Figure 3) and were categorized as isosporous. The terminal akinetes of Pithophora roettleri are generally obtuse and rounded (Figure 4).

Branches were irregularly formed throughout the thallus. Fully germinated branches developed from intercalary (Figure 3E) or from the terminal (Figure 3F) akinetes. Interrupted germination of branches into akinetes were also observed with some exhibiting a beak-like form and some divided by a transversal cell wall (Figure 5). Because the branch process in Figure 5E was more developed, the elongation of its branch assumed a $45^{\circ}$ angle to the principal filament while an akinete was formed on its upper end. Branches were also observed forming below the upper cell wall of a supporting cell (Figure 5C,D). Rhizoidal cells, zoospores, and zygotes were not observed.

\subsection{DNA Sequences}

Contiguous assemblies of Illumina reads carrying LSU and SSU rDNA sequences from our isolate were identified by their similarity to the archived $P$. roettleri SSU (aka 18S) sequence FR719930 [17]. The SSU portion of our assembly was an exact match $(100 \%$ similarity) to this archived sequence and the LSU (aka 28S) had 100\% similarity to the 
P. roettleri voucher sequence FR719942. At the time of this study, there were no 5.8S, full-length 28S, or intergenic rRNA sequences for $P$. roettleri available for comparison.

Twelve candidate chloroplast and mitochondrial sequences were also identified from Illumina sequences by their similarities to the UTEX 787 Pithophora sp. sequences reported in [26]. Eight of these gene sequences ( $a t p B, a t p H$, pet $A$, petB, $p s a B, p s b C, r b c L$, and $c o x I)$ were confirmed by PCR amplifying the coding regions and directly sequencing the amplicons with Sanger-based methodology. The confirmed coding regions were archived in GenBank (MN049185-MN049192). Sequences produced for this study are listed in Table 2. Sequences listed as "not archived" were assembled using Illumina reads but could not be PCR amplified and confirmed by Sanger sequencing. A comparison of each new gene sequence to its corresponding Pithophora sp. sequence is provided in Table 2 and Supplementary Materials. Similarities varied considerably, $76.2 \%-97.2 \%$, with those $<90 \%$, psaB, pet $A$, and $r b c L$, having incomplete Pithophora sp. coding regions, some with gaps, which are responsible for the low scores.

\subsection{Phylogenetic Analysis}

Concatenated LSU and SSU gene markers from our isolate and 24 other taxa (Table 2) were used for phylogenetic analyses since these genes were available in GenBank for a wide array of Cladophorales. The resulting tree (Figure 6) had eight groups corresponding to Aegagropila, Aegagropilopsis, Basicladia (synonymous to Arnoldiella, the latter being the current preferred name), Cladophora, incertae sedis, Pithophora, Pseudocladophora, and Wittrockiella. The most resolved LSU-SSU tree represents the combined support values. The Pithophora grouping and the support between our isolate (novel sequence) and Pithophora roettleri has strong BP and PP support values (Figure 6).

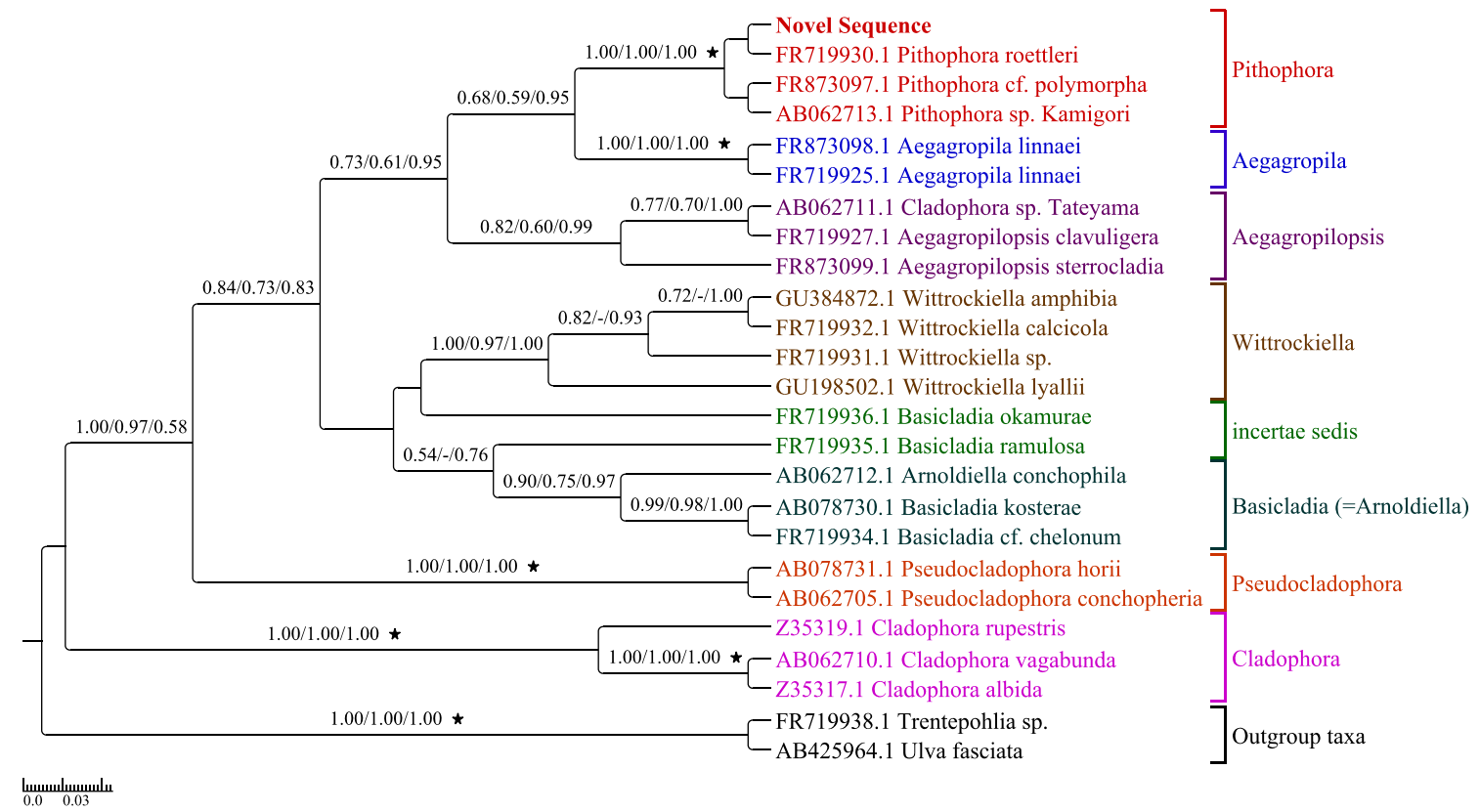

Figure 6. The most resolved concatenated LSU-SSU tree (ML) inferred with the novel sequence of Pithophora roettleri shown in bold as "Novel Sequence." The bootstrap values of ML and MP and posterior probabilities of BI greater than 0.50 are given above each branch as (ML/MP/BI). Branches with highest support values are noted with stars. Hyphens (-) indicate a branching order that does not exist for that particular inference method.

\subsection{Morphological and Molecular Phylogenetic Analyses Congruence}

According to our polyphasic approach, the consensual species-level identification of the monospecific, filamentous community was confirmed as $P$. roettleri. Thallus has cylindrical cells within primary filament diameter 120-190 $\mu \mathrm{m}$ and cell lengths are variable 
but is usually more than 20 times their diameter. Sparse lateral branches of the thallus have vegetative and reproductive cells and narrower diameters. Facultative akinetes develop fast within vegetative cells and their color depends on maturity—older akinetes look darker. Akinetes are cylindrical or sack-shaped, swollen, and arranged in series from solitary to up to seven intercalary or terminal, generally wider than the originating vegetative cell. Molecular support for the species level identification was also unquestionable based on nuclear genes.

\section{Discussion}

\subsection{Morphological Analyses}

The morphological characters observed suggested that the monospecific filamentous community was Pithophora and the species P. roettleri. Four Pithophora species from eleven described species, five of which are present in North America, were comparable of the monospecific, filamentous community in this study based on the presence of heterosporous intercalary akinetes as the most important character $[8,18,24]$. All of the intercalary akinetes of $P$. varia Willie, P. polymorpha Wittrock, P. zelleri Wittrock, and P. roettleri are either cylindrical, cask-shaped, or irregularly shaped. Due to few recorded descriptions, the species from the aforementioned studies do not contain measurements for all of the cell types of Pithophora and are reported as either averages or ranges. Some descriptive measurements of cell types vary between treatments by different studies but were incomplete.

Some species of Pitophora, i.e., P. roettleri, P. polymorpha, and P. zelleri, have been described in greater detail in older literature. All species originated from Asia but $P$. roettleri and P. polymorpha are suggested to be tropical species whereas P. zelleri is a subtropical species [24]. Although these species consist of heterosporous intercalary akinetes, the characteristics of the vegetative and reproductive cells of each species vary slightly. Pithophora varia, P. polymorpha, P. zelleri, and P. roettleri have intercalary akinetes that range from caskshaped to cylindrical to irregular, whereas $P$. polymorpha has a lower number of irregularly shaped akinetes. Similarly, the terminal akinetes are either cask-shaped or cylindrical with an obtusely pointed or rounded tip. The terminal akinetes of P. roettleri and P. polymorpha assume both shapes, whereas P. zelleri only assumes cask-shaped, terminal akinetes [18]. Furthermore, the four species are capable of developing solitary or paired akinetes. Multiple series of variously shaped intercalary and terminal akinetes have been observed in $P$. roettleri with a maximum of seven akinetes in a row [36], as also seen in this study. Pairs of $P$. roettleri akinetes are also frequently developed in the intercalary and terminal cells of branches. Twin akinetes within the principal filament assume two shapes with the upper akinete as cask-shaped and the lower akinete with a cylindrical shape [20].

The average length of the intercalary akinetes of the monospecific, filamentous community is more comparable to the lengths of P. polymorpha, P. zelleri, and P. roettleri than to $P$. varia. The average length of the monospecific, filamentous community is equivalent to $P$. roettleri, whereas the average length of $P$. polymorpha and $P$. zelleri, respectively, were smaller $[8,18,24]$. Here, we show akinetes and prolific cells being formed from the youngest vegetative cells. We also documented, as was suggested in literature [24], that the upper part of the mother cell forms the apical daughter cell as the akinete or prolific cell, whereas the lower, subapical daughter cell remains as a vegetative cell. Upon the formation of a transversal, parting cell wall, the parietal layer of chloroplast is disrupted as the cell contents of the vegetative, subapical cell are slowly transferred to the apical cell. Our results showed that the green pigmentation of the subapical cell decreases, sometimes until it is colorless (Figures 3-5), due to the significantly lower abundance of chlorophyll granules compared to the abundance in the apical cell $[18,21]$. The chloroplasts were observed to be comprised of multiple pyrenoids surrounded by starch as a food reserve in which the starch grains are microscopically visible $[19,20]$ and shown in this study. When a substantial amount of multi-nucleate protoplasm remains in the subapical cells of Pithophora, successive formations of akinetes are induced and are positioned directly below the first, oldest akinete. 
As illustrated in this study, for the first time, intercalary and terminal akinetes, unique features of the genus, developed solitarily, in pairs, or in short chains [14]. The intercalary akinetes of the monospecific, filamentous community were comparable to the length ranges of $P$. roettleri as described in older literature $[18,24]$ and $P$. polymorpha as described by van den Hoek [20]. The morphology of the principal filament is still considered even though it is less significant in species identification. Compared to the descriptions of akinetes, the size of the principal filament of Pithophora is infrequently recorded and falls in between the averages of $P$. roettleri and $P$. zelleri.

Resembling the growth of higher plants, the vegetative cells of the cauloid and rhizoid develop in opposite directions. Similar to the stem of a plant, divisions and growth of the cauloid occur apically (meristematic growth) and give rise to the vegetative and reproductive cells throughout the thallus. Similar to the root of a plant, the rhizoid exhibits growth extending below the lowest cauloid cell of the thallus $[18,20]$. The branches of Pithophora exhibit a lateral growth $[18,20,21]$. The new branches are formed acropetally with the oldest vegetative cells furthest from the apex to the youngest cells closest to the apex of the principal filament. The length of the oldest cells, closest to the branch point, are also the longest compared to the younger ones closer to the apex.

\subsection{Molecular Phylogenetic Analyses}

When comparing the concatenated LSU-SSU phylogenetic tree of Boedeker et al. [17] to the most resolved concatenated LSU-SSU tree (Figure 6), the branching order of the taxa within the clades are similar with varying support although the trees differ in topologies.

All of the phylogenetic trees inferred the relationship of the LSU and SSU novel sequences to the eight clades of Aegagropila, Aegagropilopsis, Arnoldiella, Cladophora, incertae sedis, Pithophora, Pseudocladophora, and Wittrockiella. Despite the shared morphological characteristics between Pithophora and Cladophora, the phylogeny confirmed that the LSU and SSU sequences derived from our Pithophora isolate is distinctive from that of Cladophora and is therefore not a species of Cladophora but a species of Pithophora.

\subsection{Consensual Interpretation}

Overall, the inference analyses suggested that the monospecific, filamentous community is $P$. roettleri. The morphology illustrated for the first time in this study is complemented with molecular phylogenetic analyses. At present, there are few DNA markers of this genus available in GenBank with the majority of them centered on only one gene marker, SSU. The LSU gene markers are partial sequences. The chloroplast or mitochondrial markers are the first entered in GenBank, but are not the first publicly archived organelle sequences since [26] archived some chloroplast sequences from Pithophora sp. UTEX787 in a Mendeleev database. Additionally, these sequences are from an unidentified species of Pithophora. It is suggested that these sequences were identified to genus-level solely based on previously published molecular analyses and were not preceded by detailed morphological identification (e.g., [17,37]).

\subsection{New Schematic Diagram}

Pithophora, first described in Europe in 1877, was not reported in the United States until 1887 [38]. Although the formation of akinetes and prolific cells has been described in numerous studies, the life cycle of Pithophora has not yet been fully illustrated in literature. Here, a new schematic diagram illustrates the four general steps of the asexual reproduction of an intercalary akinete (Figure 7). Similarly, an akinete of a different position along the thallus follows the same scheme. Each vegetative cell within the thallus is capable of developing an akinete that is richer in chlorophyll-colored protoplasm with the lower part remaining as a vegetative cell, the subapical cell (Figure 7: Step 1). The germination of an akinete begins with the dissociation of the vegetative cells on each end of the akinete (Figure 7: Step 2). As a cell wall develops within the akinete, the reproductive cell divides into two vegetative daughter cells, the upper cauloid cell and lower rhizoidal cell (Figure 7: 
Step 2 to Step 3). In forming a new filamentous thallus, the cauloid cell divides into two daughter cells with the upper part elongating apically to form a new cauloid cell (Figure 7: Step 3 to Step 4). Further successive elongations and divisions of the apical cauloid cells occur in the same manner to eventually form a new thallus (Figure 7: Step 4 to Step 1).

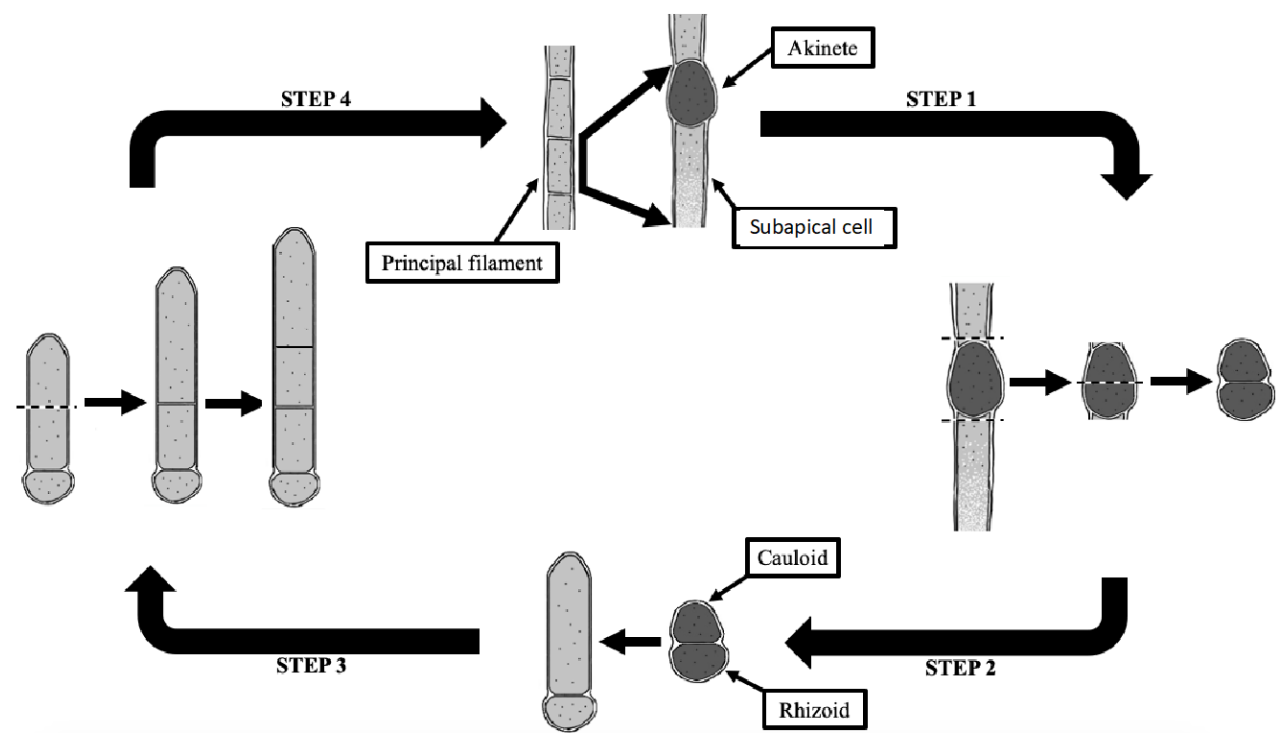

Figure 7. Schematic of the asexual reproduction of Pithophora. (Step 1) The formation of an akinete from a vegetative cell enclosed within the principle filament. (Step 2) The formation of a cauloid and rhizodal cell from the division of the akinete. (Step 3) The elongation of the cauloid cell. (Step 4) The formation of a new thallus, as in Step 1, from the further division and elongation of the uppermost cauloid cells.

\subsection{Inferred Ecology of Floating Mats}

The monospecific, filamentous community collected from the Ogeechee River in October 28, 2016, presented an opportunity to bring some understanding of nuisance algal ecology from several perspectives. In 2016, a lack of precipitation in Georgia contributed to lower water levels in all aquatic habitats, potentially higher concentrations of nutrients, lower dissolved oxygen, and slower, stagnant waters in certain areas [39]. In response to the intensified periods of drought a fast growing filaments outcompeted the phytoplankton community of the Ogeechee River. Lembi et al. [38] hypothesized that Pithophora mats were able to protect themselves from desiccation and high temperatures due to the coverage provided from the surface layer of cells. As a result of increasing desiccation, Pithophora akinetes are formed in large quantities to increase their reproduction and survival rates [38].

Considering climate change and the potential loss of ecosystem services, there is a need to understand the population dynamics of primary producers that trigger massive changes in the trophic levels above them. What was not understood before was that taxa, like $P$. roettleri, are able to quickly (in our study, less than a month) transform their vegetative cells into akinetes to give them a competitive advantage. This study helps our understanding of how and why such organisms can dominate in an ecosystem. Paerl and Huisman [40] suggested that the growth of algal blooms is expedited by changes in the hydrological cycle when global warming impacts the patterns of precipitation and drought. With an increase in water retention time and capture of nutrients, the surrounding sediment acts as a nutrient source that accelerates eutrophication and promotes nuisance or harmful algal blooms [40,41]. As these dense algal blooms become buoyant and cover the water's surface, decreased light penetration into the water column suppresses the growth of non-buoyant phytoplankton. Furthermore, algal blooms can negatively impact aquatic ecosystems that provide drinking water, recreational activities, and fishing opportunities. Nuisance algal blooms, such as the monospecific, filamentous community in this study, 
pose an ecological problem as they can persist up to weeks or months depending on the season and under favorable environmental conditions [9].

Because of the nuisance fast growth of Pithophora, it is difficult to control its population size when its akinetes are resistant to aquatic herbicides and its cells are too large for grazers [38]. The insoluble properties of the crystalline, cellulose cell wall of this alga also protects it from microbial pathogens that infect other algae [7]. Therefore, this alga can persist without competition and is able to regenerate itself. Pithophora is also known to cause anaerobic conditions in aquatic habitats when its massive biomass is digested and oxygen is depleted, resulting in fish kills [40,41].

It is suggested that epiphytic algae are associated with algal mats, which can increase species diversity, architectural structure, and physiological characteristics in natural environments [9]. Epiphytic diatoms were not observed on the monospecific, filamentous community at the time of collection, potentially due to a reduced availability of propagules of epiphytic algae. Lack of epiphytes during the morphological analysis in the lab may be due to the constant transferring of the sample to fresh medium.

\section{Conclusions}

The present research represents the first community ecological study of $P$. roettleri in Georgia, USA. Detailed morphological descriptions, DNA sequences, developmental stages, and life history are reported here for the first time and can be used in ecological monitoring. The monospecific, filamentous community collected along the Ogeechee River was identified to species-level and compared to previously published taxonomic classification and DNA markers. DNA sequence data preceded by detailed morphological identifications aided in differentiating species of Pithophora based on individual genomes despite the overlapping phenotypic plasticity in morphological characters, likewise with other genera. In this research, we updated and showed taxonomic characteristics that existed as descriptions or drawings only in literature older than 100 years. For this species, we highlighted the number, position, and fast development of the unique akinetes. We also report 17 partial or complete genes with nuclear, mitochondrial, or plastid organelle origins. As a result, this comprehensive study enhances the understanding of the fast-growing filamentous algae like $P$. roettleri and its implication in assessing the water quality of rivers subject to environmental changes and drought. Future studies can test if fast development of akinetes in this species promotes fast growth under altered conditions.

Supplementary Materials: The following are available online at https:/ / www.mdpi.com/2073-444 1/13/6/760/s1, comparison of each new gene sequence to its corresponding Pithophora sp. sequence.

Author Contributions: Conceptualization, B.L. and K.M.M.; methodology, B.L.; software, B.L. and M.J.M.; validation, A.B.C., B.L. and K.M.M.; formal analysis, B.L. and M.J.M.; investigation, B.L., M.Z. and M.J.M.; resources, B.L., M.J.M. and M.Z.; data curation, A.B.C. and K.M.M. writing-original draft preparation, B.L.; writing-review and editing, M.Z., A.B.C. and K.M.M.; visualization, B.L. and M.J.M.; supervision, A.B.C. and K.M.M.; project administration, A.B.C. and K.M.M.; funding acquisition, A.B.C. and K.M.M. All authors have read and agreed to the published version of the manuscript.

Funding: This research was funded by Georgia College and State University graduate students travel grants to B.L. and M.Z. and Georgia EPD 2016-18 Watershed \& Monitoring Program contract to K.M.M. Cost related for publication provided by Georgia College and State University Foundation (Georgia Power endowment professorship to K.M.) and student publications support from the Department of Biological and Environmental Sciences at Georgia College and State University.

Institutional Review Board Statement: Not applicable.

Informed Consent Statement: Not applicable.

Data Availability Statement: The data presented in this study are available on request from the corresponding author. The data are not publicly available as graduate work. 
Acknowledgments: The authors would like to thank all those who provided field and lab support. We are very grateful to the editor and three anonymous reviewers. This work was part of the first author's masters graduate research at the Department of Biological and Environmental Sciences at Georgia College and State University.

Conflicts of Interest: The authors declare no conflict of interest

\section{References}

1. Mittelbach, G.G. Community Ecology; Sinauer Associates, Inc. Publishers: Sunderland, MA, USA, 2012.

2. Oyedeji, A.A.; Abowei, J.F.N. The classification, distribution, control and economic important of aquatic plants. Intern. J. Fish. Aquat. Stud. 2012, 1, 118-128.

3. Awasthi, A.K. Textbook of Algae; Vikas Publishing House: New Delhi, India, 2015; pp. 169-174.

4. Fritsch, F.E. The subaerial and freshwater algal flora of the tropics. A phytogeographical and ecological study. Ann. Bot. 1907, 21, 235-275. [CrossRef]

5. Pearlmutter, N.L.; Lembi, C.A. Structure and composition of Pithophora oedogonia (Chlorophyta) cell wall. J. Phycol. 1980, 16, 602-616. [CrossRef]

6. Boedeker, C.; Leliaert, F.; Zuccarello, G.C. Molecular phylogeny of the Cladophoraceae (Cladophorales, Ulvophyceae), with the resurrection of Acrocladus Nägeli and Willeella Børgesen, and the description of Lurbica Gen. Nov. and Pseudoprhizoclonium gen. nov. J. Phycol. 2016, 52, 905-928. [CrossRef]

7. Zulkifly, S.B.; Graham, J.M.; Young, E.B.; Mayer, R.J.; Piotroeski, M.J.; Smith, I.; Graham, L.E. The genus Cladophora Kützing (Ulvophyceae) as a globally distributed ecological engineer. J. Phycol. 2013, 49, 1-17. [CrossRef] [PubMed]

8. Prescott, G.W. Algae of the Western Great Lakes Area; WM. C. Brown Co. Inc.: Dubuque, Iowa, 1962; pp. $134-144$.

9. Saunders, L.L.; Kilham, S.S.; Fairchild, G.W.R.; Verb, R. Effects of small-scale environmental variation on metaphyton condition and community composition. Freshw. Biol. 2012, 57, 1884-1895. [CrossRef]

10. Power, M.; Lowe, R.; Furey, F.; Welter, J.; Limm, M.; Finlay, J.; Bode, C.; Chang, S.; Goodrich, M.; Sculley, J. Algal mats and insect emergence in rivers under Mediterranean climates: Towards photogrammetric surveillance. Freshw. Biol. 2009, 54, $2101-2115$. [CrossRef]

11. Ansari, W.A.; Kashyap, S.P.; Prajapati, R.; Neelam, A. 2 Morpho-physiological and genetic variation of the algal collected from different water bodies of Varanasi and Chandauli region using ISSR molecular marker. Int. J. Tech. Res. Appl. $2015,3,56-61$.

12. Valiela, I.; McClelland, J.; Hauxwell, J.; Behr, P.J.; Hersh, D.; Foreman, K. Macroalgal blooms in shallow estuaries: Controls and ecophysiological and ecosystem consequences. Limnol. Oceanogr. 1997, 42, 1105-1118. [CrossRef]

13. Dodds, W.K.; Gudder, D.A. The ecology of Cladophora. J. Phyc. 1992, 28, 415-427. [CrossRef]

14. Boedeker, C. Phylogenetic, Taxonomic and Biogeographical Studies in the Pithophoraceae (Cladophorales, Chlorophyta); Wöhrmann Print Service: Zutphen, The Netherlands; Netherlands Centre for Biodiversity Naturalis: Leiden, The Netherlands, 2010.

15. Leliaert, F.; Boedeker, C. Cladophorales. In The Green Seaweeds of Britain and Ireland; Brodie, J., Maggs, C.A., John, D.M., Eds.; The British Phycological Society: London, UK, 2007; pp. 131-183.

16. Algarte, V.M.; Bichoff, A.; Dunck, B.; Rodrigues, L. First record of Pithophora oedogonia (Montagne) Wittrock (Pithophoraceae) in the Upper Paraná River floodplain, Brazil. Check List 2015, 11, 1722. [CrossRef]

17. Boedeker, C.; Kelly, C.J.O.; Star, C.J.W.; Leliaert, F. Molecular phylogeny and taxonomy of the Aegagropila clade (Cladophorales, Ulvophyceae), including the description of Aegagropilopsis Gen. Nov. and Pseudocladophora gen. nov. J. Phycol. 2012, 48, 808-825. [CrossRef] [PubMed]

18. Wittrock, V.B. On the Development and Systematic Arrangement of the Pithophoraceae, a New Order of Algae Nova Acta Regiae Societatis Scientiarum Upsaliensis Ser. 3, extra ordinem. Editum 1877, 19, 1-80.

19. Leliaert, F.; Smith, D.R.; Moreau, H.; Herron, M.D.; Verbruggen, H.; Delwiche, C.F.; de Clerck, O. Phylogeny and molecular evolution of the green algae. CRC Crit. Rev. Plant Sci. 2012, 31, 1-46. [CrossRef]

20. van den Hoek, C.; Mann, D.G.; Jahns, H.M. Algae an Introduction to Phycology; Cambridge Press University: New York, NY, USA, 1995.

21. Chaudhary, B.R.; Singh, H.V. Influence of certain environmental factors of spore germination and spore differentiation in Pithophora oedogonia. Folia Microbiol. 1987, 32, 339-344. [CrossRef]

22. Sukenik, A.; Maldener, I.; Delhaye, T.; Viner-Mozzini, Y.; Sela, D.; Bormans, M. Carbon assimilation and accumulation of cyanophycin during the development of dormant cells (akinetes) in the cyanobacterium Aphanizomenon ovalisporum. Front. Microbiol. 2015, 6, 1067. [CrossRef]

23. O'Neal, S.W.; Lembi, C.A. Physiological changes during germination of Pithophora oedogonia (Chlorophyceae) akinetes. J. Phyc. 1983, 19, 193-199. [CrossRef]

24. Collins, F.S. The Green Algae of North America; Tufts College Press: Medford, MA, USA, 1909.

25. Kapraun, D.F. Nuclear DNA content estimates in green algal lineages: Chlorophyta and Streptophyta. Ann. Bot. 2007, 99, 677-701. [CrossRef] [PubMed]

26. Del Cortona, A.; Leliaert, F.; Bogaert, K.A.; Verbrugeen, H.; Vandepoele, K.; Clerck, O. The plastid genome in Cladophorales green algae is encoded by hairpin chromosomes. Curr. Biol. 2017, 27, 1-12. [CrossRef] 
27. Meade, M.J.; Proulex, G.C.R.; Manoylov, K.M.; Cahoon, A.B. Chloroplast mRNAs are $3^{\prime}$ polyuridlylated in the green alga Pithophora roettleri (Cladophorales). J. Phycol. 2020, 56, 1124-1134. [CrossRef] [PubMed]

28. Altschul, S.F.; Gish, W.; Miller, W.; Myers, E.W.; Lipman, D.J. Basic Local Alignment search tool. J. Mol. Biol. 1990, 215, 403-410. [CrossRef]

29. Kumar, S.; Stecher, G.; Tamura, K. MEGA7: Molecular evolutionary genetic analysis version 7.0 for bigger datasets. Mol. Biol. Evol. 2016, 33, 1870-1874. [CrossRef]

30. Edgar, R.C. MUSCLE: Multiple sequence alignment with high accuracy and high throughput. Nucleic Acids Res. 2004, 32, 1792-1797. [CrossRef]

31. Ronquist, F.; Huelsenbeck, J.P. MRBAYES 3: Bayesian phylogenetic inference under mixed models. Bioinformatics 2003, 19, 1572-1584. [CrossRef] [PubMed]

32. Hall, B.G. Phylogenetic Trees Made Easy: A How-to Manual, 4th ed.; Sinauer Associates, Inc.: Sunerland, MA, USA, 2011.

33. Hall, B.G. Building phylogenetic trees from molecular data with MEGA. Mol. Biol. Evol. 2013, 30, 1229-1235. [CrossRef] [PubMed]

34. Felsenstein, J. Confidence limits on phylogenies: An approach using bootstrap. Evolution 1985, 39, 783-791. [CrossRef] [PubMed]

35. Stöver, B.C.; Müller, K.F. TreeGraph 2: Combining and visualizing evidence from different phylogenetic analyses. BMC Bioinform. 2010, 11, 7. [CrossRef] [PubMed]

36. Skinner, S.; Entwisle, T.J. Non-marine algae of Australia: 6. Cladophoraceae (Chlorophyta). Telopea 2004, 10, 731-748.

37. Hanyuda, T.; Wakana, I.; Arai, S.; Miyaji, K.; Watano, Y.; Ueda, K. Phylogenetic relationships within Cladophorales (Ulvophyceae, Chlorophyta) inferred from $18 \mathrm{~S}$ rRNA gene sequences with special reference to Aegagropila linnaei. J. Phycol. 2002, 38, 564-571. [CrossRef]

38. Lembi, C.A.; Pearlmutter, N.L.; Spencer, D.F. Life Cycle, Ecology, and Management Considerations of the Green Filamentous Algal, Pithophora; Indiana Water Res. Center Technology Reports, Paper 130; Purdue University: West Lafayette, IN, USA, 1980.

39. NOAA National Centers for Environmental Information, State of the Climate: National Climate Report for October 2016. Available online: https:/ / www.ncdc.noaa.gov/sotc/national/201610 (accessed on 15 January 2020).

40. Paerl, H.W.; Huisman, J. Blooms like it hot. Am. Assoc. Adv. Sci. 2008, 320, 57-58. [CrossRef]

41. Sundbäck, K.; Carlson, L.; Nilsson, C.; Jönsson, B.; Wulff, A.; Odmark, S. Response of benthic microbial mats to drifting green algal mats. Aquat. Microb. Ecol. 1996, 10, 195-208. [CrossRef] 